Volume 2 Nomor 2, November 2021: h. 166 - 177 P-ISSN: 2722-4465, E-ISSN: 2746-8151

Lisensi Creative Commons Atribusi-NonCommercial 4.0 Internasional

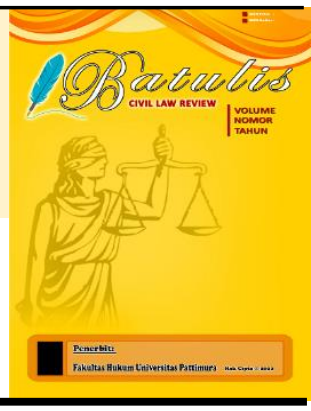

\title{
Hak Kepemilikan Perumahan Di Atas Bangunan Gedung Komersil
}

\section{Cut Hardiyanti Pangerang ${ }^{1}$, Sri Susyanti Nur ${ }^{2}$, Muhammad Ilham Arisaputra ${ }^{3}$}

1, 2, 3 Fakultas Hukum Universitas Hasanuddin, Makassar, Indonesia

E-mail: cut.hardiyanti@gmail.com

\begin{tabular}{l}
\multicolumn{1}{c}{ Dikirim: 15/01/2021 } \\
\hline Info Artikel \\
\hline Keywords: \\
Housing; Building; Proprietary \\
Rights for Flats. \\
\hline Kata Kunci: \\
Perumahan; Bangunan \\
Gedung; Hak Milik Satuan \\
\hline
\end{tabular}

\begin{abstract}
Direvisi: 30/11/2021
Abstract

This research aims to find the regulation regarding to the spatial utilization above a commercial building for housing and to examine ownership rights for housing built on top of the building. This research is an empirical legal research with research locations in DKI Jakarta, precisely at the Cosmo Park and The Villas. The research location was considered in DKI Jakarta because the existence of housing above commercial buildings in Indonesia was only in DKI Jakarta. The speakers in this research were the Head of Planning and Utilization of City Spaces at the department of copyright works, spatial planning, and land in DKI Jakarta province (DCKTRP), Building Supervision Staff at the DCKTRP DKI Jakarta province and the Directorate General of Spatial Planning at the Ministry of Agrarian Affairs and Spatial Planning / National Land Agency. The results of this research indicate that the current regulation regarding the spatial utilization above commercial buildings for housing refers to the local RTRW and RDTR whose spatial utilization allocations must be in accordance with the stipulated permits. Permits are granted in the form of location permits, space utilization permits and building construction permits in accordance with applicable local scale regulations. For the Cosmo Park and The Villas housing in DKI Jakarta, there is a mismatch between the initial IMB and the current use of the building. So the important thing that must be considered in the future construction of housing on commercial buildings is that the presentation of the IMB must be in accordance with the current construction realization. Ownership rights for housing built on top of the building, namely the property rights for flat units (strata title). Strata title refers to individual ownership of a proportionally part of a building either horizontally or vertically.
\end{abstract}

Abstrak
Penelitian ini bertujuan untuk menemukan pengaturan
mengenai pemanfaatan ruang diatas bangunan gedung komersil
untuk perumahan dan menelaah hak kepemilikan untuk
perumahan yang terbangun diatas bangunan gedung. Penelitian
ini merupakan penelitian hukum empiris dengan lokasi
penelitian di DKI Jakarta tepatnya di Perumahan Cosmo Park
dan Perumahan The Villas. Pertimbangan lokasi penelitian di
DKI Jakarta sebab keberadaan perumahan di atas bangunan
gedung komersil di Indonesia baru ada di DKI Jakarta.
Narasumber dalam penelitian ini adalah Kepala Bidang
Perencanaan dan Pemanfaatan Ruang Kota pada Dinas Cipta


DOI:

10.47268/ballrev.v2i2.737
Karya, Tata Ruang dan Pertanahan (DCKTRP) Provinsi DKI Jakarta, Staf Bidang Pengawasan Bangunan Gedung pada DCKTRP Provinsi DKI Jakarta dan Direktorat Jenderal Tata Ruang pada Kementrian Agraria dan Tata Ruang / Badan Pertanahan Nasional. Hasil penelitian ini menunjukkan bahwa Pengaturan mengenai pemanfaatan ruang di atas bangunan gedung komersil untuk perumahan saat ini mengacu pada RTRW dan RDTR setempat yang alokasi pemanfaatan ruangnya harus sesuai dengan izin yang telah ditetapkan. Bentuk pemberian izin berupa izin lokasi, izin pemanfaatan ruang dan izin mendirikan bangunan sesuai dengan peraturan berskala lokal yang berlaku. Namun untuk perumahan Cosmo Park dan The Villas di DKI Jakarta terdapat ketidak sesuaian antara IMB awal dengan penggunaan bangunan saat ini. Sehingga hal penting yang harus diperhatikan dalam pembangunan perumahan di atas bangunan gedung komersil kedepannya adalah pemberian IMB harus sesuai dengan realisasi pembangunannya saat ini. Hak kepemilikan untuk perumahan yang terbangun di atas bangunan gedung yakni Hak Milik Satuan Rumah Susun (strata title). Strata title merujuk pada kepemilikan individual secara proporsional sebagian dari sebuah bangunan gedung baik itu secara horizontal maupun vertikal.

\section{Pendahuluan}

Tanah adalah salah satu sumber daya alam yang merupakan kebutuhan yang hakiki bagi manusia dan berfungsi sangat esensial bagi kehidupan dan penghidupan manusia, bahkan menentukan peradaban suatu bangsa. Tanah dalam kehidupan manusia mempunyai arti yang sangat penting oleh karena sebagian besar dari kehidupan manusia adalah bergantung pada tanah. Tanah dapat dinilai sebagai suatu harta yang mempunyai sifat permanen dan dapat dicadangkan untuk kehidupan pada masa mendatang (Arisaputra, 2015: 55). Tanah sebagai salah satu sumber daya agraria merupakan kekayaan nasional yang manfaatnya diperuntukkan untuk sebesar besar kemakmuran rakyat sebagaimana yang diamanatkan dalam Pasal 33 ayat (3) Undang-undang Dasar Negara Republik Indonesia Tahun 1945 (UUD 1945). Sebagai wujud peranan hukum dalam pengaturan penggunaan tanah agar dapat bermanfaat bagi kesejahteraan rakyat, maka landasan hukum pertanahan nasional kita adalah Undang-undang Nomor 5 Tahun 1960 tentang Peraturan Dasar Pokok Pokok Agraria (UUPA) (Nur, 2006: 5).

Undang-undang Nomor 26 Tahun 2007 tentang Penataan Ruang (UUPR) menyebutkan pengertian ruang adalah wadah yang meliputi ruang darat, ruang laut, dan ruang udara, termasuk ruang di dalam bumi sebagai satu kesatuan wilayah. Penataan ruang yang baik perlu diwujudkan agar kualitas ruang wilayah nasional dapat terjaga keberlanjutannya demi terwujudnya kesejahteraan umum dan keadilan sosial sesuai dengan landasan konstitusional UUD 1945. Dalam memanfaatkan ruang, setiap orang wajib menaati rencana tata ruang dan 
memanfaatkan ruang sesuai dengan izin yang telah ditetapkan. Ketentuan mengenai pemanfaatan ruang diatur dalam bagian kedua UUPR pada Pasal 32 dan Pasal 33.

Seiring dengan laju perkembangan pembangunan terutama di kota besar yang begitu pesat, pemanfaatan tanah tidak hanya terbatas pada permukaan bumi saja tetapi juga telah berkembang dengan memanfaatkan ruang atas tanah dan ruang bawah tanah melalui pendirian bangunan tiga dimensi (above the land, on the land, and under the land). Tiga dimensi yang dimaksudkan adalah pendirian bangunan selain memanfaatkan bidang/permukaan bumi, juga ruang udara di atas permukaan bumi, serta ruang di bawah tanah/dalam tubuh bumi. Pada konteks pemanfaatan ruang atas tanah inilah secara sederhana bahwa bangunan berdiri di atas tiang tiang atau tonggak tonggak, sehingga terdapat ruang antara bangunan dengan permukaan tanah atau bangunan tidak melekat secara langsung pada permukaan tanah (Arsyad, 2015: 3).

Salah satu ciri dari kawasan perkotaan adalah banyaknya bangunan gedung yang terbangun yang diatur dalam Undang-undang Nomor 28 Tahun 2002 tentang Bangunan Gedung (UUBG). Pembangunan gedung harus berdasarkan persyaratan administratif dan persyaratan teknis. Dengan banyaknya bangunan gedung yang terbangun maka penataan dan pemanfaatan ruang kawasan perkotaan perlu mendapat perhatian yang khusus, terutama yang terkait dengan penyediaan wilayah perumahan dan permukiman agar suatu daerah tidak menjadi kacau akibat tidak tertata dengan baik. Perumahan dan permukiman merupakan salah satu kebutuhan dasar manusia yang pemenuhannya terus diupayakan agar semakin besar lapisan masyarakat dapat menempati rumah dengan lingkungan permukiman yang layak, sehat, aman dan serasi. Pasal 28 H UUD 1945 mengamanahkan bahwa rumah adalah salah satu hak dasar rakyat dan oleh karena itu, setiap warga Negara berhak untuk bertempat tinggal dan mendapat lingkungan hidup yang baik dan sehat (Amir et al., 2014). Saat ini, pengaturan mengenai perumahan diatur dalam Undang-undang Nomor 1 Tahun 2011 tentang Perumahan dan Kawasan Permukiman selanjutnya disingkat UU Perumahan (UU Perumahan).

Pasal 22 UU Perumahan mengklasifikasikan bentuk bentuk rumah yaitu; rumah tunggal, rumah deret, dan rumah susun. Pengklasifikasian ini berarti membedakan definisi antara ketiga bentuk rumah tersebut. Selanjutnya Pasal 38 ayat (4) UU Perumahan menyebutkan bahwa pembangunan rumah dan perumahan harus dilakukan sesuai dengan RTRW. Artinya setiap pembangunan perumahan harus berdasarkan izin yang mengacu pada Perda RTRW dimana perumahan tersebut akan dibangun. Selama ini pemenuhan kebutuhan akan rumah sebagai tempat tinggal atau hunian di perkotaan dilakukan melalui pembangunan perumahan secara horizontal. Cara pemenuhan kebutuhan ini tidak dapat dilakukan secara terus menerus disebabkan oleh persediaan tanah di perkotaan yang sangat terbatas. Maka dari itu, pemenuhan kebutuhan akan rumah sebagai tempat tinggal atau hunian di perkotaan ditempuh melalui pembangunan rumah susun (Santoso, 2014: 401). Pengaturan mengenai rumah susun diatur dalam Undang-undang No. 20 Tahun 2011 tentang Rumah Susun. (UURS). 
Kepemilikan atas rumah susun berbeda dengan rumah tunggal atau rumah deret yang biasa kita kenal dengan rumah tapak (landed house). Dalam Pasal 43 undang-undang perumahan, status hak yang didapatkan oleh pemilik landed house dapat diberikan hak milik dan hak hak atas tanah sebagaimana diatur dalam UUPA. Sedangkan kepemilikan untuk rumah susun bersifat strata title, dengan kepemilikan sebatas satuan unit rumah susun yang dimiliki, tidak mencakup seluruh bangunan dari rumah susun dan tidak termasuk tanah di dalam lingkungan rumah susun dan apa yang ada di bawahnya serta apa yang ada di atasnya (Sutedi, 2010: 146).

Salah satu contoh perumahan yang berkembang di Indonesia adalah Perumahan Cosmo Park di atas Mall Thamrin City tepatnya di lantai 10 dan Perumahan The Villas di atas Mall of Indonesia tepatnya di lantai 5. Kedua perumahan ini terbangun dengan konsep town house berbentuk rumah tapak karena bangunannya terpisah dengan rumah lainnya namun berada di ruang atap mal. Lingkungan perumahannya pun dilengkapi dengan prasarana, sarana dan utilitas yang lengkap seperti di cluster perumahan mewah pada umumnya seperti jalan aspal, ruang terbuka hijau dan sarana olahraga. Kedua perumahan ini juga dilengkapi dengan akses khusus menuju mal.

Hal penting dalam pembangunan perumahan dengan konsep yang sama seperti perumahan The Villas dan Cosmo Park adalah memperhatikan aspek persyaratan teknis dan persyaratan administratif dalam UUBG. Jika terdapat kesalahan pada konstruksi bangunan, maka yang menjadi taruhan adalah kepentingan orang banyak dan kerugian terhadap pemilik hak atas tanah yang ada di bawahnya. Ketentuan mengenai Sertifikat Laik Fungsi (SLF) sesuai undangundang bangunan gedung tentunya harus terpenuhi karena perumahan ini telah difungsikan. Selain itu, aspek zonasi peruntukan lahan yang sesuai dengan Perda RTRW DKI Jakarta juga menjadi perhatian yang khusus. Terlebih lagi belum ada peraturan yang spesifik mengatur tentang pemanfaatan ruang di atas bangunan gedung untuk perumahan. Karena belum adanya aturan maka bisa saja setiap pengembang dapat dengan bebas membangun perumahan dengan konsep sama tanpa memperhatikan aspek keselamatan, namun hanya memikirkan keuntungan (benefit) semata. Terkait IMB yang dikeluarkan oleh pemerintah DKI Jakarta, yang menjadi pertanyaan adalah apakah yang menjadi acuan dalam pemberian izin untuk pembangunan perumahan Cosmo Park dan The Villas, mengingat belum adanya aturan mengenai hal tersebut. Hal penting lainnya adalah mengenai status kepemilikan setiap unit rumah yang ada dalam perumahan tersebut.

\section{Metode Penelitian}

Penelitian ini merupakan penelitian hukum empiris yaitu suatu metode penelitian hukum yang menggunakan fakta-fakta empiris yang diambil dari perilaku manusia, baik perilaku verbal yang didapat dari wawancara maupun perilaku nyata yang dilakukan melalui pengamatan langsung (Fajar \& Achmad, 2017: 280). Lokasi penelitian di DKI Jakarta dengan pertimbangan sebab keberadaan perumahan di atas bangunan gedung komersil di Indonesia baru ada di DKI Jakarta tepatnya di 
Perumahan Cosmo Park dan Perumahan The Villas, dengan narasumber yakni Kepala Bidang Perencanaan dan Pemanfaatan Ruang Kota pada Dinas Cipta Karya, Tata Ruang dan Pertanahan (DCKTRP) Provinsi DKI Jakarta, Staf Bidang Pengawasan Bangunan Gedung pada DCKTRP Provinsi DKI Jakarta dan Direktorat Jenderal Tata Ruang pada Kementrian Agraria dan Tata Ruang / Badan Pertanahan Nasional. Pendekatan penelitian menggunakan pendekatan perundang-undangan dan konseptual. Jenis dan sumber data menggunakan data primer yakni informasi yang penulis peroleh melalui wawancara langsung dengan narasumber dan data sekunder yakni informasi yang penulis peroleh secara tidak langsung yang meliputi buku-buku, karya ilmiah, jurnal, dokumen-dokumen yang memiliki relevansi dengan penelitian ini serta beberapa peraturan perundang-undangan baik yang berskala lokal maupun nasional. Analisis data dilakukan secara kualitatif untuk mencapai titik jelas dari masalah yang diangkat dan hasilnya akan diuraikan secara deskriptif.

\section{Hasil dan Pembahasan}

\subsection{Hak-Hak Atas Tanah Dalam Hukum Tanah Nasional}

Hak atas tanah, dapat diperoleh melalui peralihan hak sebagaimana yang diatur dalam Undang-Undang Pokok Agraria (UUPA) (Tomasoa et al., 2021), dalam hukum agraria nasional, khusus mengenai hukum tanah terdapat macam macam hak penguasaan atas tanah yang dapat disusun dalam hierarkhi sebagai berikut (Arba, 2015: 85-86):

a. Hak Bangsa Indonesia diatur dalam Pasal 1 UUPA;

b. Hak Menguasai Negara diatur dalam Pasal 2 UUPA;

c. Hak Ulayat masyarakat masyarakat hukum adat sepanjang menurut kenyataannya masih ada diatur dalam Pasal 3 UUPA;

d. Hak-hak individu atau hak-hak perorangan yang terdiri dari:

1) Hak-hak atas tanah diatur dalam Pasal 4, berupa:

a) Hak primer, yaitu hak atas tanah yang diatur dalam Pasal 16 ayat (1) terdiri dari: Hak Milik, Hak Guna Usaha, Hak Guna Bangunan, Hak Pakai, Hak Sewa, Hak Membuka Tanah, Hak Memungut Hasil Hutan, Hak-hak lain yang tidak termasuk dalam hak-hak tersebut di atas akan ditetapkan dengan Undang-Undang serta hak-hak yang sifatnya sementara sebagai yang disebutkan dalam Pasal 53.

b) Hak sekunder (hak-hak yang bersifat sementara) yang diatur dalam Pasal 53 yang terdiri dari: Hak Gadai, Hak Usaha Bagi Hasil, Hak Menumpang, Hak Sewa Tanah Pertanian.

2) Hak-hak atas air dan ruang angkasa yang dimaksud dalam Pasal 4 ayat (3) dan diatur lebih lanjut dalam Pasal 16 ayat (2), yaitu: Hak Guna Air, Hak Pemeliharaan dan Penangkapan Ikan, Hak Guna Ruang Angkasa.

3) Hak Wakaf yang diatur dalam Pasal 4, yang diatur lebih dengan Peraturan Pemerintah Nomor 28 Tahun 1977 tentang Perwakafan Tanah Milik. 
4) Hak Tanggungan yang diatur dalam Pasal 23, 33, 39, 51 dan diatur lebih lanjut dalam Undang-Undang Nomor 4 Tahun 1996 tentang Hak Tanggungan Atas Tanah.

\subsection{Tinjauan Umum Tentang Perumahan dan Penataan Ruang}

Salah satu tujuan dibentuknya Negara Republik Indonesia ialah memajukan kesejahteraan umum. Untuk memajukan kesejahteraan umum dilaksanakan pembangunan nasional, yang hakikatnya yaitu pembangunan manusia Indonesia seutuhnya dan pembangunan seluruh rakyat Indonesia yang menekankan pada keseimbangan pembangunan kemakmuran lahiriah dan kepuasan batiniah. Rumah sebagai tempat tinggal mempunyai peran yang sangat strategis dalam pembentukan watak dan kepribadian bangsa sebagai salah satu upaya membangun manusia Indonesia seutuhnya, berjati diri, mandiri, dan produktif sehingga terpenuhinya tempat tinggal merupakan kebutuhan dasar bagi setiap manusia, yang akan terus ada dan berkembang sesuai dengan tahapan atau siklus kehidupan manusia (Santoso, 2014: 2).

Tugas dan wewenang pemerintah, pemerintah provinsi dan pemerintah kabupaten/kota dalam melaksanakan pembinaan penyelenggaraan perumahan dan kawasan permukiman diatur dalam Pasal 12 sampai dengan Pasal 18 UU Perumahan. Pembangunan perumahan dapat diselenggarakan oleh badan usaha yang berbentuk Perseroan Terbatas (PT), Badan Usaha Milik Negara yang berbentuk Perusahaan Perseroan (Persero), Badan Usaha Milik Negara yang berbentuk Perusahaan Umum (Perum), Lembaga Negara, Kementrian, Lembaga Pemerintah non kementrian, Pemerintah Provinsi, Pemerintah Kabupaten/Kota, Badan Otoritas, Yayasan (Santoso, 2014: 187).

Tata ruang sebagai wujud penataan ruang merupakan sarana (instrument hukum) untuk menjamin dan mengharmoniskan berbagai kepentingan pembangunan ekonomi, sosial, budaya, maupun kepentingan ekologi dalam arti yang luas (Wahid, 2016: 8). Tata ruang sebagai wujud penataan ruang pada intinya merupakan sarana untuk mewujudkan pembangunan berkelanjutan. Pembangunan itu tidak saja untuk memecahkan masalah peningkatan kesejahteraan masa sekarang tetapi juga peningkatan kesejahteraan jangka panjang. Konsep pembangunan berkelanjutan mengakomodasikan tujuan pertumbuhan ekonomi, tujuan pengentasan kemiskinan, dan pengelolaan sumber alam dan lingkungan dalam rangka pemenuhan kebutuhan jangka panjang dan tujuan tersebut konsisten satu sama lain (Wahid, 2016: 11).

Penaatan ruang berisi arahan peruntukan dan pemanfaatan ruang yang tidak lain adalah arahan yang berkorelasi dengan peruntukan dan pemanfaatan tanah. Arahan tersebut diatur dalam peraturan perundang-undangan untuk memberikan kepastian hukum dan kekuatan mengikat baik kepada pemerintah daerah maupun kepada masyarakat. Bagi pemerintah daerah, penataan ruang merupakan dasar untuk melakukan berbagai tindakan sesuai dengan arahan atau perencanaan yang telah tercantum dalam RTRW (Saleng, 2013: 138-139). 


\subsection{Pengaturan Pemanfaatan Ruang Di Atas Bangunan Gedung Untuk Perumahan}

Pasal 4 ayat (2) UUPA menentukan macam-macam hak atas permukaan bumi. Atas dasar hak menguasai Negara memberi wewenang untuk mempergunakan tanah yang bersangkutan demikian pula tubuh bumi dan air serta ruang yang ada diatasnya, sekedar diperlukan untuk kepentingan yang langsung berhubungan dengan penggunaan tanah itu dalam batas-batas menurut UUPA. Sehingga ketentuan dalam UUPA ini dapat menjadi dasar dan rujukan dalam peraturan yang mengatur pemberian izin bagi pemanfaatan ruang di atas bangunan gedung komersil untuk perumahan.

Tabel 1.

Terminologi izin dalam peraturan yang menjadi dasar pembangunan perumahan Cosmo Park dan The Villas

\begin{tabular}{llllr}
\hline \multicolumn{1}{c}{ Izin Lokasi } & \multicolumn{2}{c}{$\begin{array}{c}\text { Izin Pemanfaatan } \\
\text { Ruang }\end{array}$} & \multicolumn{2}{c}{ Izin Mendirikan } \\
Bangunan
\end{tabular}




\begin{tabular}{|c|c|c|}
\hline & $\begin{array}{l}\text { peraturan } \\
\text { perundangundangan, } \\
\text { sebagai dasar untuk } \\
\text { mendapatkan izin } \\
\text { mendirikan } \\
\text { bangunan." }\end{array}$ & $\begin{array}{l}\text { mengurangi bangunan } \\
\text { gedung sesuai dengan } \\
\text { persyaratan } \\
\text { administratif dan } \\
\text { teknis yang berlaku." }\end{array}$ \\
\hline $\begin{array}{l}\text { Pasal } 4 \text { \& } \text { Pasal } 6 \\
\text { Pergub DKI Jakarta } \\
\text { Nomor 209/2016 } \\
\text { tentang Perizinan dan } \\
\text { Rekomendasi } \\
\text { Pemanfaatan Ruang: } \\
\text { Setiap orang yang akan } \\
\text { melakukan } \\
\text { pemanfaatan ruang } \\
\text { wajib memiliki izin dari } \\
\text { Gubernur berupa izin } \\
\text { lokasi sebagai dasar } \\
\text { untuk mendapatkan } \\
\text { IMB. }\end{array}$ & $\begin{array}{l}\text { Pasal } 4 \text { \& Pasal } 6 \\
\text { Pergub DKI Jakarta } \\
\text { Nomor 209/2016 } \\
\text { tentang Perizinan dan } \\
\text { Rekomendasi } \\
\text { Pemanfaatan Ruang: } \\
\text { Setiap orang yang akan } \\
\text { melakukan } \\
\text { pemanfaatan ruang } \\
\text { wajib memiliki izin dari } \\
\text { Gubernur berupa izin } \\
\text { pemanfaatan ruang } \\
\text { sebagai dasar untuk } \\
\text { mendapatkan IMB. }\end{array}$ & 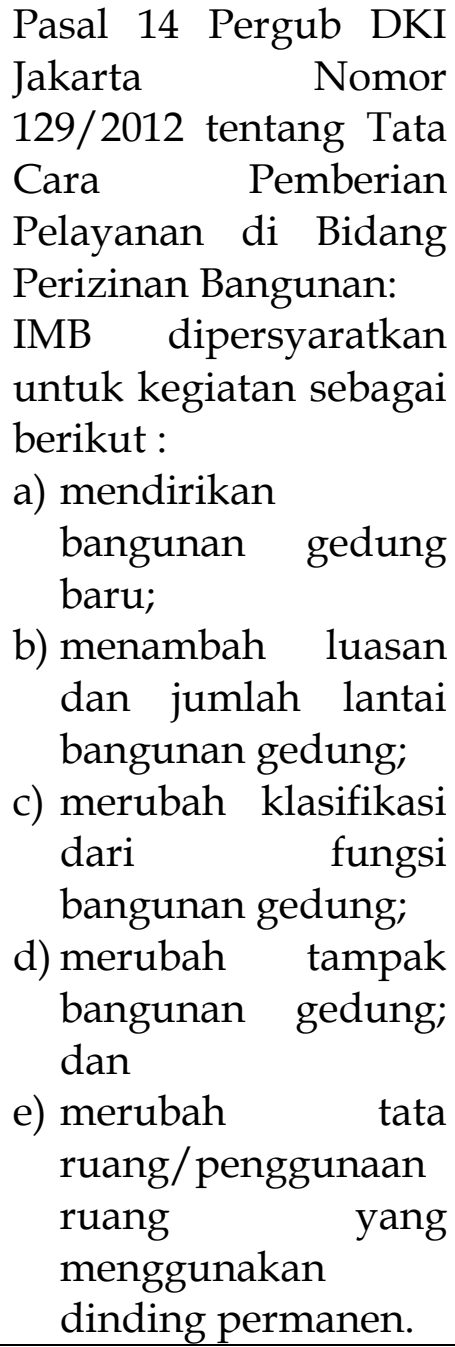 \\
\hline
\end{tabular}

Dari peraturan di atas dapat dilihat bahwa mengubah dan memperluas bangunan gedung juga harus memperoleh IMB. Ahmad Sobirin, staf Bidang Pengawasan Bangunan Gedung DCKTRP Provinsi DKI Jakarta mengatakan bahwa IMB Thamrin City terbit 2 kali, yang pertama pada tahun 2005 dengan nomor IMB 11815/IMB/2005 yang dimohonkan pada tahun 2004 dengan peruntukan penggunaan untuk kantor, hotel dan toko. IMB pertama sudah sesuai mengingat di Thamrin City sendiri memang digunakan untuk kantor pengembang, hotel amaris, dan toko-toko sebagai pusat perbelanjaan di Kawasan Tanah Abang, namun tidak ada keterangan penggunaan untuk perumahan. Kemudian IMB kedua terbit pada tahun 2009 dengan nomor IMB 8507/IMB/2009 yang permohonannya juga pada tahun 2009 dengan penggunaan untuk pertokoan dan hotel. Dapat dilihat dalam IMB 
Thamrin City bahwa tidak ada peruntukan penggunaan untuk perumahan berbentuk landed house.

Kemudian untuk IMB Mall of Indonesia terbit pada tahun 2006 dengan nomor IMB 3359/IMB/2006 yang dimohonkan pada tahun 2005 dengan peruntukan penggunaan untuk kantor, hotel, dan toko. Sama dengan Thamrin City, pada IMB Mall of Indonesia juga tidak ada keterangan bahwa peruntukan penggunaan dari bangunan gedung tersebut adalah untuk perumahan (landed house). Berdasarkan data IMB ini, dapat disimpulkan bahwa tidak ada permohonan pengajuan IMB baru yang diajukan pihak pengembang kepada pemerintah. Karena persyaratan administratif bangunan gedung yang kurang lengkap, sehingga berdampak pada persyaratan teknis yang tidak memadai yakni ketentuan keandalan bangunan gedung yang ditinjau dari aspek 4K, yaitu aspek keselamatan, kesehatan, kenyamanan dan aspek kemudahan bangunan gedung yang dimuat dalam UUBG. Implikasinya, Sertifikat Laik Fungsi dari bangunan thamrin city dan mall of Indonesia menjadi dipertanyakan. Sehingga hal penting yang harus diperhatikan dalam pembangunan perumahan di atas bangunan gedung komersil kedepannya adalah dalam pemberian IMB, pemerintah daerah harus memperhatikan kesesuaiannya dengan realisasi pembangunan saat ini.

Abdul Kamarzuki, Dirjen Tata Ruang pada kementrian ATR/BPN mengatakan bahwa dalam menyusun Tata Ruang harus berdasarkan fungsi dari pemanfaatan ruang. Menurutnya, seharusnya tidak ada masalah dalam pemberian izin pemanfaatan ruang untuk Thamrin City dan Mall of Indonesia karena dari segi tata ruang, wilayahnya untuk kepentingan komersil sudah sesuai untuk pemberian Hak Guna Bangunan ataupun Hak Pakai. Pada kesempatan lain, Heru Sunawan, Kepala Bidang Perencanaan dan Pemanfaatan Ruang Kota pada DCKTRP Provinsi DKI Jakarta mengatakan bahwa dasar pemberian izin bagi pembangunan perumahan Cosmo Park dan The Villas adalah RTRW 2030 dan dari sisi kegiatan sudah sesuai dengan zonasi dan pemanfaatan ruang berdasarkan Perda RTRW.

\subsection{Hak Kepemilikan Perumahan Di Atas Bangunan Gedung Komersil}

Meskipun konsep perumahan di atas bangunan gedung belum dikenal sebagai salah satu jenis rumah dalam UU Perumahan dan Permukiman, namun hukum harus responsif dan tidak tertatih-tatih mengikuti perkembangan zaman. Kepastian hukum harus hadir untuk menjamin kepemilikan rumah di atas bangunan gedung. Saat ini, kepemilikan rumah di perumahan Cosmo Park dan The Villas adalah Hak Milik atas Satuan Rumah Susun (strata title). Heru Sunawan mengatakan bahwa perumahan Cosmo Park dan The Villas masih tergolong sebagai apartemen meskipun bentuknya landed house karena posisinya dapat dikategorikan sebagai lantai teratas sebuah bangunan gedung bertingkat dan konsep kepemilikannya masih strata title.

Sistem kepemilikan atas bangunan bertingkat sudah dikenal di Indonesia, namun sistem kepemilikan atas gedung bertingkat tersebut adalah berupa sistem kepemilikan tunggal dimana pemilik seluruh gedung dan pemegang hak-hak atas tanahnya merupakan pihak yang sama. Jika ada pihak lain yang ingin menggunakan bagian dari gedung tersebut, maka ia harus melakukan hubungan sewa-menyewa 
dengan pemilik gedung, penghuni dan pengguna bagian tersebut menjadi dimungkinkan untuk memiliki sebagian dari gedung tersebut dan juga sebagian atas tanah tempat gedung tersebut berdiri secara proporsional pemilikan bagian-bagian gedung-secara individual dimungkinkan dalam bentuk Hak Milik atas Satuan Rumah Susun (HMSRS) (Ramelan et al., 2015: 1).

Strata title merujuk pada konsep kepemilikan atas hunian yang dibangun secara vertikal, entah itu condominium, apartemen, atau rumah susun. Jika rumah susun dibangun di atas Hak Milik, maka rumah susun tersebut hanya dapat dimiliki oleh warga Negara Indonesia atau badan hukum Indonesia yang ditetapkan oleh pemerintah Indonesia. Jika rumah susun dibangun di atas Hak Guna Bangunan, maka rumah susun dapat dimiliki oleh warga Negara Indonesia dan badan hukum Indonesia yang berdomisili di Indonesia. Ini adalah konsep yang paling banyak digunakan dan tersedia di Indonesia. Sebagian besar bangunan strata title dibangun di atas Hak Guna Bangunan. Jika dibangun di atas Hak Pakai maka hak tersebut dapat dimiliki oleh warga Negara Indonesia, warga Negara asing, badan hukum Indonesia dan badan hukum asing yang mempunyai perwakilan di Indonesia. Hak ini adalah alas hak terbaik yang dapat dimiliki secara langsung oleh warga Negara asing atau badan hukum asing. Salah satu alasannya adalah bahwa hal tersebut tidak umum bagi warga negara Indonesia maupun badan hukum Indonesia untuk memiliki hak tersebut (Ramelan et al., 2015: 11-12).

Perbedaan konsep hak milik (SHM) pada rumah biasa (landed house) dengan strata title yaitu apabila seseorang membeli rumah biasa di komplek perumahan, kepemilikannya biasanya berupa sertifikat Hak Milik. Orang yang memiliki Sertifikat Hak Milik berdasarkan sistem hukum Indonesia (UUPA) sangat kuat dan bersifat selamanya yang kepemilikannya meliputi bangunan di atas tanah, tanah di halaman rumahnya, tanah yang berada di bawahnya serta apa yang ada di atas bangunan tersebut. Adapun apabila seseorang membeli apartemen atau rumah susun maka sertifikat hak miliknya bukan SHM seperti rumah biasa namun konsep kepemilikannya bersifat strata title (Sutedi, 2010: 146).

Jika Anda membeli unit Satuan Rumah Susun (Sarusun), Anda memiliki dua jenis Hak/Kepemilikan, yaitu (Kallo, 2009: 76-77):

1) Kepemilikan Bersama, yang dimiliki secara bersama-sama secara proporsional dengan para pemilik lainnya pada Rumah Susun tersebut yang terdiri dari:

a) Tanah bersama, adalah sebidang tanah yang digunakan atas dasar hak bersama secara tidak terpisah yang di atasnya berdiri Rumah Susun dan ditetapkan batasnya dalam persyaratan izin bangunan. Yang dapat dijadikan tanah bersama dalam pembangunan rumah susun adalah tanah-tanah yang berstatus/bersertifikat hak milik, HGB, atau hak pakai. Mengingat penyelenggara pembangunan (pengembang) berbadan hukum, maka tanah bersama itu akan bersertifikat induk HGB. Nantinya HGB tersebut tidak dipecah tetapi akan diberi keterangan. Isi keterangan ialah bahwa HGB tersebut telah melahirkan 
beberapa sertifikat hak milik satuan Rumah Susun (SHM Sarusun) dan tidak dapat dialihkan atau dijaminkan.

b) Bagian bersama, adalah bagian Rumah Susun (melekat pada struktur bangunan) yang dimiliki secara tidak terpisah untuk pemakaian bersama dalam satu kesatuan fungsi dengan satuan Rumah Susun. Contohnya fondasi, atap, lobi, lift, saluran air, jaringan listrik, gas, dan telekomunikasi.

c) Benda bersama, adalah benda yang bukan merupakan bagian Rumah Susun (tidak melekat pada struktur bangunan), tetapi dimiliki bersama secara tidak terpisah untuk pemakaian bersama. Contoh, tanah, tempat parkir, kolam renang yang diluar struktur, dan lain-lain.

2) Kepemilikan perseorangan, adalah hak kepemilikan atas unit sarusun ruangan dalam bentuk geometrik tiga dimensi yang dibatasi oleh dinding dan digunakan secara terpisah atau tidak bersama-sama. Adapun dinding yang menopang struktur bangunan merupakan bagian bersama. Hak ini akan tergambar dalam pertelaan rumah susun tersebut dan luas/ukuran unit sarusun akan diuraikan dalam SHM sarusunnya.

\section{Kesimpulan}

Pengaturan mengenai pemanfaatan ruang di atas bangunan gedung komersil untuk perumahan saat ini mengacu pada RTRW dan RDTR setempat yang alokasi pemanfaatan ruangnya harus sesuai dengan izin yang telah ditetapkan. Bentuk pemberian izin berupa izin lokasi, izin pemanfaatan ruang dan izin mendirikan bangunan sesuai dengan peraturan berskala lokal yang berlaku. Namun untuk perumahan Cosmo Park dan The Villas di DKI Jakarta terdapat ketidak sesuaian antara IMB awal dengan peruntukan bangunan saat ini. Sehingga hal penting yang harus diperhatikan dalam pembangunan perumahan di atas bangunan gedung komersil kedepannya adalah pemberian IMB harus sesuai dengan realisasi pembangunannya saat ini. Hak kepemilikan untuk perumahan yang terbangun di atas bangunan gedung yakni Hak Milik Satuan Rumah Susun (strata title). Strata title merujuk pada konsep kepemilikan individual secara proporsional sebagian dari sebuah bangunan gedung baik itu secara horizontal maupun vertikal. Hal penting dalam kepemilikan strata title adalah pertelaan karena dari pertelaan tersebut akan muncul satuansatuan yang terpisah secara hukum melalui proses pembuatan akta pemisahan yang harus berdasarkan pada izin mendirikan bangunan

\section{Daftar Referensi}

Amir, H., Salle, A., \& Nur, S. S. (2014). Kegiatan Bank Tanah-Sebagai Bentuk Penyediaan-Tanah Untuk Permukiman-Rakyat. Analisis, 3(1), 29-36.

Arba, H. M. (2015). Hukum Agraria Indonesia. Sinar Grafika.

Arisaputra, M. I. (2015). Reforma Agraria Di Indonesia. Sinar Grafika.

Arsyad, M. (2015). Pemanfaatan Ruang Atas Tanah di Atas Jalan Raya di Kota Makassar. Universitas Hasanuddin. 
Fajar, M., \& Achmad, Y. (2017). Dualisme Penelitian Hukum Normatif dan Empiris. Pustaka Pelajar.

Kallo, E. (2009). Tanya Jawab Hukum Properti. Majalah IDEA.

Nur, S. S. (2006). Aspek Hukum pelaksanaan penataan Ruang Kota Dalam Mewujudkan Kota Mandiri "Tanjung Buga (GTC) Di Kota Makassar.

Ramelan, E., Hartanto, J. A., Handajadi, S., \& Sekarmadji, A. (2015). Perlindungan Hukum Bagi Konsumen Pembeli Satuan-Rumah-Susun/Strata-Title/Apartemen. Aswaja Pressindo.

Saleng, A. (2013). Kapita Selekta Hukum Sumberdaya Alam. Membumi Publishing.

Santoso, U. (2014). Hukum Perumahan. Kencana Prenadamedia Group.

Sutedi, A. (2010). Hukum Rumah Susun E Apartemen. Sinar Grafika.

Tomasoa, G. P. T., Tjoanda, M., \& Matuankotta, J. K. (2021). Hak Atas Tanah Dan Bangunan Berdasarkan Pelepasan Hak (Studi Kasus Putusan MA Nomor 2523 K/Pdt/2015). TATOHI: Jurnal Ilmiah Hukum, 1(3), 206-219. https://fhukum.unpatti.ac.id/jurnal/tatohi/article/view/571

Wahid, A. M. Y. (2016). Pengantar Hukum Tata Ruang. Prenadamedia Group. 